松下茂*

株式会社サンメディア

\section{I ，本コースの狙(注)}

2002 年から, 大学図書館, 企業内図書館や情報担当 部署, 病院図書館などで著作権への関心が高まっている。 その背景には，複写利用と著作権を巡る新聞各紙の報道 や国公私立大学図書館協議会著作権問題協力委員会によ る著作権対策の取り組みの進展がある。

本コースは，大学図書館が直面している著作権問題の 中で特に複写権を巡る現状の動きと課題を平易に解説す ることで, 受講者がその理解を深め, 現場で直面する問 題解決の一助となることを目的とした。

本稿は, 2002 年 11 月に筆者が行なった講義をその後 の著作権関連の動きをアップデートしてまとめたもので ある。講義のまとめという性格から本稿での記載内容は, 他の拙稿屯含めてすでに多くの最近の著作権関連記事で 紹介されている内容と重複している点があることを， あ らかじめ申し述べておきたい。

\section{3 つの著作権処理機関}

国内における複写利用に関する著作権処理機関は, 次 の 3 機関である。

\section{1. 社団法人日本複写権センター（以下，JRRC）}

英名は，Japan Reprographic Rights Center。設立 は, 1991 年で 1998 年には当時の文部省によって社団法 人の認可を受けた。ホームページは, http://www.jrrc. or.jp。

JRRC は，4つの権利者組織によって構成されてい る。脚本家などで構成される著作者団体連合, 商業出版 者の各業界団体によって構成される出版者著作権協議会,

*Shigeru MATSUSHITA： ₹164-0012 東京都中野区本町 3-10-3. PORT91 Tel.03-5371-8541 Fax.03-5371-3750

matsushita@sunmedia.co.jp

（2003 年 3 月 17 日 受理）
学協会団体によって構成される学術著作権協会, 61 社 の新聞社で構成される新聞著作権協議会である。新聞著 作権協議会は, 日本新聞協会内での著作権対応への議論 の結果として 2002 年 6 月に誕生した。 2002 年 9 月に日 本複写権センターに加盟し 2002 年 4 月から遡って著作 権処理が JRRC で行なわれることになった。

JRRC は,「日本複写権センターニュース」を年に 1 回 7 月に発行し事業報告を行なっている。2002 年 7 月 に発行された同ニュースによれば，2002 年 3 月時点で, 契約者数は 3,478 機関, 著作権料収入は 1 億 5,600 万円 となっている。また複写利用の多い学術分野に関係する 著作物を管理する出版者著作権協議会の加盟出版社は, 176 社である。

また JRRC は，国際的な権利処理機関の連合体であ る International Federation of Reproduction Rights Organisations（IFRRO）の日本代表である。

JRRC で可能な権利処理は, 国内管理著作物の電子 化を除く複写に関する複製権及び FAX を利用しての公 衆送信権, 複製後の外部提供の 3 種類である。詳細は, 「複写利用の手引き」及び「使用料規定」に記載されて いる。

\section{2. 株式会社学術著作権処理システム（以下，ACCS)}

英名は, Academic Copyright Clearance System。 設立は, 2002 年 2 月で, 同年 4 月より営業を開始して いる。ACCS は, 後述する著作権等管理事業法に適応 するため学術著作権協会に権利委託された著作物の複写 許諾実務を行なう。

学術著作権協会 (Japan Academic Association for Copyright Clearance：JAACC）は, 1989 年の学協会 著作権協議会として設立され，その後学術著作権協会に 改名。ホームページは, http://wwwsoc.nii.ac.jp/jaacc/。 JAACC は, 前述 JRRC の構成機関であるが, JAACC の管理する国内管理著作物の複写利用のうちで 個別許諾（複写のたびに複写許諾を行うこと）や外部提 
供目的の複写許諾は JRRC では扱わず，JAAC が直接 に許諾を行なう。最新更新デー夕は 2002 年 7 月時点で, 617 学協会の 1,241 定期刊行物と 1,505 単行本の管理著 作物を管理している。

また米国の著作権処理機関であるCopyright Clearance Center (CCC) と双務契約を 1999 年 12 月に 締結しており，CCC の管理著作物のうち日本への権利 処理委託が可能な約 2,200 著作権者の著作物の日本国内 での権利処理空口となっている。

JAACC を通じて可能な権利処理で特徵的なことは, 一部の国内学協会著作物の電子化とその印刷に関しての 許諾が得られることである。奈良先端科学技術大学院大 学の電子図書館資料の一部むこの権利処理を通じて電子 化が実現した。その他の国内管理著作物については, 複 写に関する複製権及び FAX を利用しての公衆送信権, 複製後の外部提供の 3 種類である。CCC の管理著作物 あ同様である。

\section{3. 株式会社日本著作出版権管理システム（以下， JCLS)}

英名は, Japan Copyright Licensing System。設立 は, 2001 年 1 月 25 日で, 社団法人自然科学書協会, 日 本医書出版協会を中心に設立された。ホームページは, http://www.jcls.co.jp。

設立の経緯は, JRRC が 2000 年 12 月の理事会で当 時の「日本複写権センター利用規定」にあった特別な許 諾を必要とする著作物の扱いを中止したことにある。こ の特別な許諾を必要とする著作物には，白抜きで「R」 の文字が奥付に記されていた。「白抜き R」の著作物は, 複写を行なう前に著作権者に複写許諾を事前に求める必 要があり， 1 ページあたり 10 円から 20 円の著作権料金 が各著作権者によって設定されていた。

この取り扱い業務を JRRC が中止したことで,「白抜 き $\mathrm{R} 」$ の著作物を出版していた自然科学系, 医書系出 版者が JCLS を設立することとなった。

2003 年 3 月時点で, 100 社, 23,420 の著作物を管理 している。そのうち, 定期刊行物は 353 タイトルである。 JCLS を通じて可能な権利処理は, 著作物の電子化を 除く複製権及び FAX を利用しての公衆送信権, 複製後 の外部提供の 3 種類である ${ }^{3}$ (表 1 )。

\section{III. 契約の種類}

これら 3 つの権利処理機関が用意している利用者向け
の契約には次のようなものがある。詳細は, 表を参照し て頂くとして基本的には次のようにまとめられる。

\section{1. 包括契約 (Blanket License)}

主として機関向けの契約で, 利用機関が所蔵している 著作物を機関内でのみ複写利用する際に必要な契約。こ の契約は，一定期間に複写実態調査を行って大凡の利用 者一人当たりの年間複写枚数を計算し, 大凡の 1 年間の 複写料金を割り出して年に一回著作権料金を支払う方法。

$J R R C$ の場合は, 一人 2 円で年間 20 枚（一人年間 40 円）の複写が行なわれるという仮定の上で従業員数分の 著作権料金を各契約機関が支払うこととなっている。

この契約方法は, JRRC, JAAC, JCLS のいずれも 対応しているかその予定をしている。現在は, 2003 年 3 月時点で, 実際に包括契約を利用者と締結しているのは JRRC のみである。

またこの契約方法では, 複写利用した個々の著作物名 や複写部数, 複写ページ数の報告は必要ない。ただし複 写部数については, JRRC の場合は 20 部以内, 複写部 分は著作物全体の $30 \%$ また 60 ページ以下のいずれか 少ない方の範囲での複写という限定がされている。

JAAC が準備している CCC 管理著作物の「調査・年 間許諾方式」(AAS：Annual Authorizations Service) は, 包括契約の一つではあるが実態調查にもとづいて業 種別に年間使用料を決める方式であり, JRRC が行なっ ているような著作物 1 ページ 2 円，一人年間 40 円とい う業種を問わないフラットな料金体系にもとづく契約と 異なる。

\section{2. 個別許諾契約 (TRS：Transactional Reporting Service)}

個別許諾契約は, 著作物の複写利用の際にその著作物 名や出版者名, 複写ページ数, 複写部数を具体的に報告 し，著作権料金を支払う方法である。報告方法には，大 きく二通りの方法がある。一つは, 複写利用する前にあ らかじめ複写利用許諾を求める方法でもう一つは 3 ヶ月 に一回の頻度で複写利用を行なった全ての著作物を事後 報告する方法である。後者の方法は, 主としてドキュメ ントデリバリーサービスを商業目的で行なうドキュメン トサプライヤー用の契約である。

個別許諾契約は，3つの権利処理機関のいずれもが対 応している (表 2 )。 
表 1. 国内権利処理機関の許諾の種類 2003 年 3 月現在

\begin{tabular}{|c|c|c|}
\hline $\begin{array}{c}\text { 社団法人日本襍写センター } \\
\text { (JRRC) }\end{array}$ & $\begin{array}{c}\text { 株式会社学術著作権処理システム } \\
\text { (JAAC) }\end{array}$ & $\begin{array}{c}\text { 株式会社日本著作出版権管理システム } \\
\text { (JCLS) }\end{array}$ \\
\hline 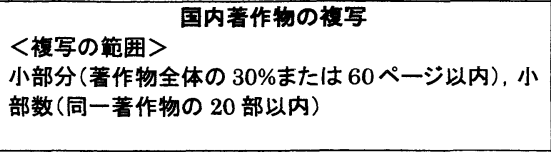 & 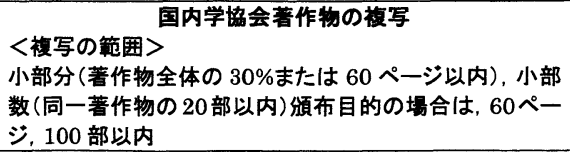 & $\begin{array}{l}\text { 国内商莱出版者著作物の複写 } \\
\text { ＜複写の範囲〉> } \\
\text { 各著作物によって異なる }\end{array}$ \\
\hline $\begin{array}{c}\text { 複写使用料単洒 } \\
1 \text { ページ } 2 \text { 円 }\end{array}$ & $\begin{array}{c}\text { 複写使用料単俩 } \\
1 \text { ページ } 2 \text { 円 } \\
1 \text { }\end{array}$ & $\begin{array}{l}\text { 複写使用料単価 } \\
1 \text { ページ } 10 \text { 円〜 } 100 \text { 円, } 1 \text { 論文 } 500 \text { 円など著作物によ } \\
\text { って異なる。 }\end{array}$ \\
\hline $\begin{array}{c}\text { 頒布目的(外部提供)の場合の使用料 } \\
\text { 提供料金の } 10 \% \text { または } 1 \text { ページ } 2 \text { 円のうち } \\
\text { いずれか高い金額 } \\
\end{array}$ & 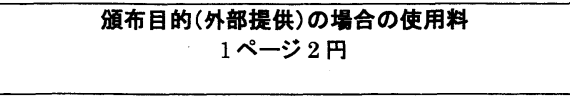 & $\begin{array}{c}\text { 頒布目的 (外部提供)の場合の使用料 } \\
\text { 上記、複写使用料金単価と同じ }\end{array}$ \\
\hline $\begin{array}{c}\text { 著作物の FAX 送信 } \\
\text { 提供料金の } 10 \% \text { または } 1 \text { ページ } 2 \text { 円のうち } \\
\text { いずれか高い金額 }\end{array}$ & $\begin{array}{c}\text { 萻作物の FAX 送倍 } \\
1 \text { ページ } 10 \text { 円 }\end{array}$ & $\begin{array}{c}\text { 著作物の FAX } \\
\text { 被写使用料金に含まれる }\end{array}$ \\
\hline $\begin{array}{c}\text { 著作物の電子化、蕃積、回僄 } \\
\text { 未対応 }\end{array}$ & 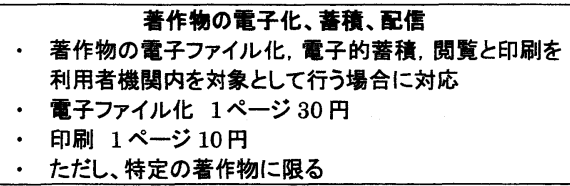 & $\begin{array}{c}\text { 著作物の雷子化、蓄積、眍信 } \\
\text { 未対応 }\end{array}$ \\
\hline $\begin{array}{l}\text { 海外著作物の複写 } \\
\text { ·CCCと } 10 \text { 年間交渉を行ってきたが, 複写使用料 } 2 \text { 円 } \\
\text { が安すぎるとして、CCC から交涉打ち切りの連絡を受 } \\
\text { ける。海外著作物の許諾は不可。 }\end{array}$ & $\begin{array}{l}\text { 海外著作物の複写 } \\
\text { CCC 管理著作物の TRS,AAS 非独占契約 } \\
\text { 部数, 機関内利用, 機関外入手, 機関外提供に拘わらず } \\
1 \text { ページ } 50 \text { 円 }\end{array}$ & $\begin{array}{l}\text { 海外著作物の複写 } \\
\text { JAAC とは別に, CCC 及び海外出版者と直接契約を模 } \\
\text { 討中。すでに Elsevier, Wiley, LWW, New England } \\
\text { Journal of Medicine, Nature と交涉。 }\end{array}$ \\
\hline $\begin{array}{l}\text { * 使用料規定を参照 } \\
\text { http://www.jrrc.or.jp/disclosure/shiyoryo.html }\end{array}$ & $\begin{array}{l}\text { ＊ 使用料規定を参照 } \\
\text { http://wwwsoc.nii.ac.jp/jaacc/new_page_3.htm }\end{array}$ & *使用料規定なし \\
\hline
\end{tabular}

\section{IV. 著作権等管理事業法}

2001 年 10 月に著作権等管理事業法が施行された。こ れは, 従来から著作権の管理事業に適用されてきた「著 作権二関スル仲介業務二関スル法律」（仲介業務法）を 廃止して制定されたものである。

著作権等管理事業法(以下，「管理事業法」) の特徴は,

1 ) 管理事業対象を従来の音楽・小説・脚本加著作権・

著作隣接権全般に拡大したこと

2 ）管理事業業務を許可制から登録制にしたこと

3 ）使用料規定の届出制と協議・裁定制度を設けたこと である。

「管理事業法」にもとづいて著作権管理事業を行なう 機関は, 民法, 商法, その他の特別法により法人格を持 つ必要があることから任意法人学術著作権協会は, その 権利処理実務に対応するためにJAAC を設立した。

「管理事業法」にもとづく「使用料規定」（著作権料 金や許諾の種類などを示した規定）の登録には，事前に 利用者の意見を聞く必要があるとされており，管理事業 の対象分野で $50 \%$ 以上の管理事業シェアを持つ管理事 業者は,「指定管理事業者」と呼ばれ利用者の求めがあ れば利用者代表と「使用料規定」について協議すること が義務付けられている。

「管理事業法」に登録しなくても著作権許諾処理を行 なうことは可能であり, 「管理事業法」以前から著作権 処理は必要であった。しかし, 著作権管理事業を行なう
機関にとっては「管理事業法」に登録することで社会的 認知を受けることとなるため，前述した 3 つの権利処理 機関は管理事業者登録を行なっている。なお，JCLS は まだ使用料規定を登録していない。

2002 年 3 月時点で, 言語・音楽・美術・図形・写真 などの分類で 29 の管理事業者が登録されている。

「管理事業者」の詳しい解説や管理事業者の一覧は, 文化庁のホームページに記載されている。

\section{V．文化審議会著作権分科会と著作権法改正}

2003 年 1 月に新聞各紙で, 映画の著作権が 70 年延長 されるなどの著作権法の改正案が今国会に上程される報 道が行なわれたことで，著作権に関しての関心が大きく 高まった。特に著作権法 31 条図書館では, 38 条の 「営利を目的としない上映」が改正され，著作権者の許 諾が必要となる可能性があることから，現行法下での図 書館の権利が制限されることへの危惧がうまれている。

今回の著作権法改正案は, 文化審議会著作権分科会と その各ワーキンググループによる議論の結果である。と くに図書館に関係する著作権法については，「著作権分 科会情報小委員会図書館等における著作物等の利用に関 するワーキンググループ」，「著作権分科会情報小委員会 著作物等の教育目的の利用に関するワーキンググループ」 での議論の結果が反映されている。これらのワーキング グループでの議論は,「文化審議会著作権分科会審議経 
表 2. 国内権利処理機関の契約の種類 2003 年 3 月

\begin{tabular}{|c|c|c|}
\hline $\begin{array}{c}\text { 社団法人日本複写権センター } \\
\text { JRRC }\end{array}$ & $\begin{array}{c}\text { 株式会社学術著作権処理システム } \\
\text { JAAC }\end{array}$ & $\begin{array}{c}\text { 株式会社日本著作出版権管理システム } \\
\text { JCLS }\end{array}$ \\
\hline 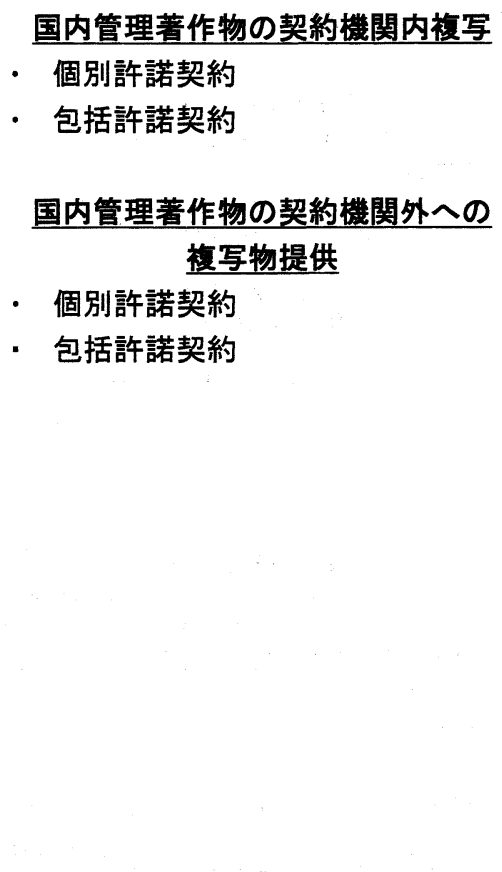 & 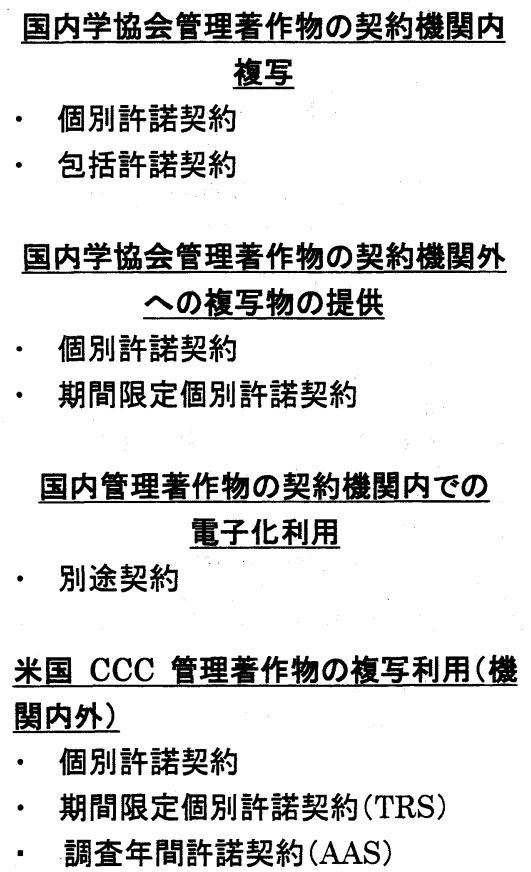 & 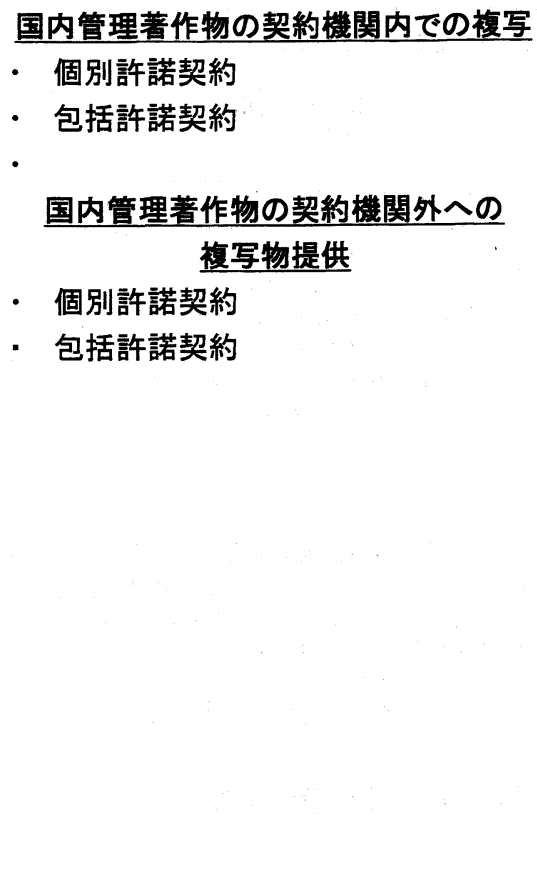 \\
\hline
\end{tabular}

過報告」として文化庁のホームページで公開されてい る。 ${ }^{6)}$

前述の図書館における映画上映については，本報告書 15 ページの「(2)図書館等の権利制限の見直し 法改正 を行なう方向とすべき事項 2 . 図書館などの公共施設 等において映画の著作物等を上映することについて権利 制限の対象から除外すること」として記載されている。

また図書館側が求めていた許諾を得ずにファクシミリ 等による公衆送信で複製物を提供する権利は, 一旦は図 書間側と権利者側で合意にいたったものの「引き続き関 係者間の協議が行なわれる事項」となった。

その他, 教師の監督下での生徒による学習目的での複 製, 遠隔地の学習者や受験者へ複製物を公衆送信するこ と，再製手段の入手が困難な図書館資料を許諾なく複製 すること，などが法改正を必要とするとして報告されて いる。

\section{VI. 利用者の動き}

\section{1. 大学図書館}

国立大学図書館協議会では, 長い間 JRRC と交渉を 重稀ることで大学図書館での著作権対応を「著作権問題
についてのアクションプラン」としてまとめた。その後, 国公私立大学図書館協議会著作権問題協力委員会は, 著 作権問題拡大ワーキンググループを通じて「大学図書館 における著作権問題 Q\&A」を作成し, 現場での著作権 対応のガイドラインを示している。

さらに 2001 年 12 月, 2002 年 10 月の 2 回にわたって 大学図書館向けの著作権問題に関するワーキングショッ プが開催され，多くの図書館員が参加した。

\section{2. 社団法人情報科学技術協会 (INFOSTA)}

INFOSTA では, 図書館や情報担当者に著作権の最 新情報の提供や利用者の立場に立った提案を行なってい る。

2001 年 4 月に設けられた複写問題検討委員会は, 2002 年 4 月に複写問題対策委員会として INFOSTA の 正規委員会として発展改組された。

利用者向けの 3 度にわたる文献複写問題検討会の開催 や文化庁, 各権利処理機関への提言・要望書の提出を通 じて，利用者への情報提供と啓発が行なわれている。

これらの活動や利用者向け参考文献の紹介は, ホーム ページを通じて広報されている。 
継続教育コース 1 「著作権を巡る動きについて : 特に複写権を中心に」

\section{3. 企業}

企業の中でも，製薬業界は薬事法による厚生労働省や 医療現場への情報提供, 研究開発のための文献情報入手 が不可欠となっている。そのため一部の権利処理機関は, 製薬会社との著作権処理契約を他の企業に優先する動き を見せている。これに対応するため，2002 年 4 月より 日本製薬団体連合会（日薬連）加盟の製薬会社有志が, 各権利処理機関と意見交換を重ねてきた。昨年 7 月には, 有志各社による複写実態調査が行なわれ，その結果にも とづいて製薬会社特有の条件を考慮した複写許諾方法の 検討が続いている。 ACCS との間では, CCC の管理著 作物に関しての複写許諾について協議が進展したため, すでに先行して著作権処理を行なっている製薬会社に次 いで, 2003 年 4 月より各製薬会社が ACCS との契約に あとづく著作権処理を開始する準備に入っている。

またその他の研究開発型企業との間でも, ACCS は 著作権処理に関しての契約を進めている。

\section{4. その他}

病院図書館では, 医療現場における医師, 看護士, 薬 剤師, その他コメディカルの実践的な要望に応じて, 必 要な文献情報を提供しており複写利用も多い。

近畿病院図書室協議会は, 2000 年 10 月に 20 周年記 念として「病院図書館と著作権」のシンポジゥムを開催 した。さらに2001年 7 月には，「病院図書館（室）にお ける文献複写についての見解」を文化庁著作権課に提出 し, 病院図書館における学術文献複写利用の社会性, 公 共性を訴えている。

日本病院会全国病院図書室研究会でも 2000 年 10 月に 「病院図書室と著作権」と題した講演会を開催した。

また病院図書室研究会は「医療法」を根拠として, 病 院図書室は著作権法 31 条, 著作権法施行令にもとづく 「著作物等の複製等が認められる施設等」であるとの見 解を打ち出した。

また，企業図書館に従事する担当者同士の情報交換を 目的とした「複写と著作権メーリングリスト」 ${ }^{9)}$, 「複写 と著作権を考えるホームページ ${ }^{10)}$ が開設されている。

なお 2002 年 4 月以降, 「薬学図書館」 2002 年 47 巻 2 号「特集 文献複写の著作権を巡る問題」,「図書館雑誌」 2002 年 96 巻 5 号, 6 号「特集 図書館と著作権法の今 日的状況と課題」「特集 図書館と著作権法のこれから を考える」,「病院図書館」 2002 年 22 巻 3 号「著作権の 現状と将来一病院図書館との関わり」,「ほすぴたるらい ぶらりあん」 2002 年 27 巻 4 号「News／著作権をめぐ
る話題」など, 各誌で著作権の関連記事が相次いで掲載 されている。

\section{VII. 当面する課題}

学術著作物の複写利用に関しての著作権問題は, よう やくその解決のための動きが始まったにすぎない様相を 呈している。権利処理機関のかかえる問題点も多いため, 現状では図書館及び利用者にとって多くの解決すべき課 題が生じている。現時点での問題点, 課題は下記である。

1. 権利処理機関が 3 つ分かれていることによる利用 者の不便。また, 各権利処理機関によって異なる権 利処理契約実務が生じる煩雑さ。

2. JRRC の著作権問題解決と権利処理機関の統一に 向けたイニシアチブの欠如。

3. 印税または学術雑誌論文単価を大きく上回る国内商 業誌の著作権使用料。

4. 著作物の電子化とその保存と再利用, インターネッ トを介した公衆送信によ゙の権利処理機関も対応して いない点。

5. 3 つの権利処理機関を併せても複写利用される学術 著作物のシェアが $30 \%$ 前後と非常に低いこと。

6. 法的規制または学術研究目的による複写利用に対し ての特別対応が久如。

7.「使用料規定」作成時に, 利用者側からの十分な要 望が反映されていない。

8. 文化審議会著作権分科会の審議委員に, 実際の複写 利用者である企業や病院図書館からの代表が選出さ れていない。

9. 図書館エンドューザー, 複写利用エンドューザーの 著作権啓発。

現在, EU では EU 各国の著作権法が一つの著作権法 によって一元管理されようとしている。これは, EUCD $(\text { EU Copyright Directive })^{11)}$ の各国への適用之言う形 で進められようとしているが，その適用期限である 2002 年 12 月を過ぎてもギリシャとデンマークをのぞく 各国は，国内での反対意見が生じており適用できていな い。EUCD では，各国の著作権法規定にあった Fair U se, Fair Dealingによる権利制限規定がみとめられて いない。これが各国の利用者の反対を呼んでいる。英国 では, 適用期限を 2003 年 3 月 31 日まで延ばしたが, さ らにその延長が必要となっている。

日本国内でも, 図書館と利用者の既得権を守り時代に 
応じた円滑で合理的な学術著作物の著作権処理システム を確立するために, 利用者と各権利処理機関との協議と 話し合いが必要である。

\section{参考サイト}

1 ）社団法人日本複写権センター http://www.jrrc.or.jp/info.html http://www.jrrc.or.jp/disclosure/shiyoryo.html [accessed 2003-05-07]

2 ）学術著作権協会.

http://wwwsoc.nii.ac.jp/jaacc/new_page_3.htm [accessed 2003-05-07]

3 ）株式会社日本著作出版権管理システム. http://www.jcls.co.jp [accessed 2003-05-07]

4 ）社団法人日本複写権センターにおける契約の種類. http://www.jrrc.or.jp/disclosure/shiyoryo.html [accessed 2003-05-07]

5 ), 6 ) 文化庁.

http://www.bunka.go.jp [accessed 2003-05-07]

7 ）国公私立大学図書館協議会著作権問題協力委員会. 大学図書
館における著作権問題 Q\&A.

http://wwwsoc.nii.ac.jp/anul/Kdtk/copyrightQA.pdf [accessed 2003-05-07]

8 ）社団法人情報科学技術協会.

http://www.infosta.or.jp [accessed 2003-05-07]

9 ）複写と著作権メーリングリスト. http://members.tripod.co.jp/copy_and_copyright/copy_ $\mathrm{ml} . \mathrm{html}$ [accessed 2003-05-07]

10）複写と著作権を考えるホームページ http://members.tripod.co.jp/copy_and_copyright/ [accessed 2003-05-07]

11) EUCD (EU Copyright Directive). http://www.cla.co.uk/directive/index.html [accessed 200305-07]

\section{参考文献}

i ) 松下 茂: 著作権の現状と将来一病院図書館との関わり. 病 院図書館 22(3)，128-136，2002

ii）松下 茂：切望される利用者の声を反映した著作権処理シス テムの確立. 薬学図書館 48(1)，3-6, 2003

注）本稿は 2002 年 11 月 28 日に大阪大学附属図書館で開催された第 9 回医学図書館研究会・継続教育コースにおいて「継続教育コース $1 」$ として講演した内容をまとめたものである。 